\title{
Firm's financial risk vulnerability: evidence from Nigeria
}

\author{
Etumudon Ndidi Asien \\ Department of Banking and Finance, \\ Faculty of Management Sciences, \\ Federal University Otuoke, \\ P.M.B. 126 Yenagoa, Bayelsa State, Nigeria \\ Email: asienen@fuotuoke.edu.ng \\ Email: ndidi_66@yahoo.co.uk
}

\begin{abstract}
This paper examines mean differences in working capital items (liquidity ratio, quick ratio, cash ratio and cash conversion days) and financial leverage of at-risk and not-at-risk firms. The paper also examines association between working capital items and financial leverage. Four hypotheses are tested using data from 2015 online annual financial statements of 89 quoted firms from ten industry sub-sectors classified by the Nigerian Stock Exchange. The data were analysed using paired samples t-tests and OLS multiple regressions. T-test results suggest that there are significant differences in working capital items and financial leverage of not-at-risk and at-risk firms. Comparisons of at-risk and not-at-risk firms suggest that, except for cash ratio, the association between working capital items and financial leverage is not equal for the two groups of firms. Result from the pooled sample suggests that working capital items are significantly associated with financial leverage. The results are not sensitive to industry membership. The pooled model, not-at-risk model and at-risk model explains, respectively, about $67 \%, 31 \%$, and $94.7 \%$ of the variation in financial leverage. The paper recommends that even though firms have enough cash they could still borrow to augment their capital structure.
\end{abstract}

Keywords: working capital; financial leverage; median; risk vulnerability; multiple regressions; credit rating; Nigeria.

Reference to this paper should be made as follows: Asien, E.N. (2017) 'Firm's financial risk vulnerability: evidence from Nigeria', Int. J. Auditing Technology, Vol. 3, No. 3, pp.184-200.

Biographical notes: Etumudon Ndidi Asien received his $\mathrm{PhD}$ Management (with specialisation in Accounting and Finance) from Surrey Business School, University of Surrey, Guildford, UK. He has lectured in universities around the world, including Kampala International University, Uganda, where he was a Senior Lecturer; Ittihad University, Ras Al Khaimah, and the American University in the Emirates, United Arab Emirates, where he was an Assistant Professor in the College of Business Administration, lecturing accounting and finance courses. Currently, he is with the newly established Federal University Otuoke, Bayelsa State, Nigeria where he lectures accounting and finance courses at the undergraduate level. His research interests include, but not limited to, accounting manipulation, accounting theory, corruption, corporate disclosure, capital market information efficiency, auditing, credit ratings, behavioural finance, international finance, and asset pricing. 


\section{Introduction}

In this paper, we examine firms financial risk vulnerability by focusing on working capital items and financial leverage. ${ }^{1}$ We bifurcate 89 firms into not-at-risk and at-risk companies because their data differ from those of the median/target company. Companies face working capital and financial risk vulnerability if their working capital items (financial leverage) are below (above) the target, which is the company that has the median value. The median is thought to provide a better idea of a typical target or optimal working capital and financial leverage. With respect to working capital items, we define not-at-risk (at-risk) firms as those whose values are above (below) the median company's working capital items values, following the methodology of Afrifa (2016) and Altman and Rijken (2012). With respect to financial leverage, we define not-at-risk (at-risk) companies as those whose financial leverage is below (above) the median company's financial leverage value. This definitions or distinctions allow us to discriminate between matched samples of not-at-risk and at-risk companies in the ensuing analyses conducted in this paper.

Risk vulnerability of financial leverage is primarily a function of the relative amount of long-term debt to total equity plus long-term debt that is above the median firm's value. A high proportion of debt increases the likelihood that firms will be unable to deliver on obligating interests and principal repayments, if their earnings are low, which portends some level of financial risk. Ross et al. (2006) argue that financial leverage increases the potential for financial distress and business failure. Working capital risk vulnerability is the risk that a firm will be unable to meet its current or short-term financial obligations from its current assets. It follows then that at-risk firms are more likely to face financial risk vulnerability. According to Ross et al. (2006), the more liquid a business is, the less likely the business is to experience financial distress, which means less difficulty in paying off debts or buying needed assets.

Gumparthi et al. (2011) find that financial risk is the most significant of all risks because it has a direct influence on the loss of value of monetary assets and liabilities (Lungu et al., 2010). In this paper, companies described as at-risk use more debt in their capital structure. Bearing the nomenclature of not-at-risk and at-risk companies in mind two-fold objectives are examined in this paper: One is to examine whether there are differences between working capital items (including net current assets, liquidity ratio, quick ratio, cash ratio, cash conversion days) and financial leverage of not-at-risk and at-risk firms. The second is to examine whether working capital items and financial leverage are associated, using OLS multiple regressions methodology.

This paper differs from most prior Nigerian papers (e.g., Falope and Ajilore, 2009; Akinlo, 2011; Uremadu and Efobi, 2012; and Uremadu et al., 2012) that examined working capital in relation to some other constructs such as profitability, firm performance, capital structure, and/or leverage. Akinlo (2011) investigates the determinants of leverage using six main independent variables of sales growth, tangibility, profitability, liquidity, size, and business environment. Uremadu and Efobi (2012) examine the impact of capital structure and liquidity on corporate profitability, using return on equity as a proxy for corporate profitability. Falope and Ajilore (2009) and Uremadu et al. (2012) examine the relationship between working capital management, liquidity and corporate profitability among quoted companies in Nigeria, using return on assets as a proxy for corporate profitability. Falope and Ajilore (2009), 
Uremadu et al. (2012) and Uremadu and Efobi (2012) specify profitability or corporate performance as their dependent variable. In our current paper working capital is made the independent variables, as in Akinlo (2011).

The closest paper to ours is Akinlo (2011), who investigates the determinants of working capital by using the six main independent variables enumerated above. Unlike in our paper, liquidity is the only working capital item in Akinlo (2011); so that, strictly speaking, Akinlo (2011) did not examine the relationship between 'working capital' and leverage. In this respect, Akinlo's (2011) explanatory variables are not the same as the variables in our paper. Our working capital items are found in Lin et al. (2011), Coyne et al. (2012), Altman and Rijken (2012), and Moosa and Sbeti (2012). However, in terms of model specification, Akinlo (2011) is similar to our paper because it specifies financial leverage as dependent variable.

Our paper's methodology can be useful in the absence of credit ratings of most non-financial services companies in Nigeria. Hence, our paper is of importance to risk managers and financial analysts who would like to build practical book value risk models. For example, they can use the paper's median financial health check methodology to determine risk vulnerability. The result can also be of importance to investors in their decision to allocate scarce resources amongst companies.

The remainder of this paper is organised as follows. The next section provides a brief review of related literature and presents the hypotheses. Section 3 addresses research design and methodology. Section 4 presents empirical results while Section 5 concludes, and recommends.

\section{Review of related literature and hypotheses}

\subsection{Review of related literature}

The importance of working capital cannot be over-emphasised because it is a major determinant of a company's operability in the short-term with regards to liquidity, solvency, survival, and profitability of the firm. Lyngstadaas and Berg (2016) and Amélia and Gama (2015) provide empirical evidence that working capital management has an effect on the profitability of small- and medium-sized firms. According to Kargar and Blumenthal (1994), if working capital management is not given due considerations then firms may fail and go into bankruptcy. The set of elements of working capital examined in this paper such as liquidity, acid test, cash and cash conversion cycle plays a vital role in the life of any company. Adequate liquidity can be appreciated when a firm is able to meet current/short-term obligations that become due for payment. Liquidity is a prerequisite for the very survival of the firm. Liquidity is measured based on the current ratio, which indicates firms' ability to meet short-term liabilities. The higher the ratio, the better it is for a firm. A company with current ratio greater than two is rated highly, and as less risky. Current ratio measures the relation between current assets and current liabilities. Current ratio indicates the ability of a company to settle current obligations from current or liquid assets. Quick ratio is a more penetrating ratio than current ratio. Quick ratio measures the ability to settle short-term obligations with current assets without closing inventory. Cash ratio belongs to the family of liquidity ratios. Cash can be considered as the life-blood of many companies. Proper management of companies' most liquid resources is vital to their survival and growth. Indeed, Wasiuzzaman (2015) 
argues that investors prefer firms that follow a more restrictive working capital policy. Cash ratio signals the ability of a company to settle current liabilities balance with the most liquid assets of the company. Cash conversion cycle can be a dynamic measure of a company's liquidity as changes in cash conversion cycles length are used for firms' liquidity analysis (e.g., Hutchison et al., 2007). Lyngstadaas and Berg (2016) and Amélia and Gama (2015), who studied working capital management of small- and medium-sized companies in Norway and Portugal, respectively, found that reducing cash conversion cycle increases company profitability.

\subsubsection{Financial leverage}

Financial leverage is one important factor that affects a firm's long-term financial risk. Use of the term leverage is imprecise in the literature. Both in research and in practice, there appears to be uncertainties in defining financial leverage. Four alternative definitions of leverage are offered by Rajan and Zingales (1995). One definition is that leverage is the ratio of total liabilities to total assets. Second definition is that leverage is the ratio of total debt to net assets after deducting account payables and other current liabilities. Third definition is that leverage is the ratio of total interest-bearing debt to total assets. Fourth definition is that leverage is the ratio of total debt to capital structure, where capital structure is defined as total debt plus equity. ${ }^{2}$ This paper adopts the last definition of leverage. The literature has problems with whether to use book value or market value of leverage. It is observed (see Moosa and Sbeti, 2012) that the choice of accounting methods can influence book values. Oscillations in market values can change leverage even when there are no changes in fundamentals (the amount of outstanding debt or the book value of equity). A strand of the literature such as Fama and French (2000) and Thies and Klock (1992) supports the use of book values because they are thought to provide a better representation as they are within the control of management. Market value depends on a number of factors beyond the direct control of managers. The literature, thus, motivates this paper's use of ratio of the book value of total long-term debt to the book value of total assets as its measure of financial leverage.

Higher financial leverage implies greater financial risk for the shareholders of a firm (see Wasiuzzaman, 2015). As indicated, debt signifies increasing risk of financial distress. Prior papers such as Minton and Schrand (1999) and Singh (2012) argue that capital structure impacts cash. In particular, Minton and Schrand (1999) argue that when the financial structure of a company is not sound, the cash flow on capital investment or R\&D investment is under the average of the industry. Singh (2012) argues that capital structure affects cash flows of companies. Lenders of long-term funds discern the health of a company based on its long-term financial strength, which is measured by the ability of the company to pay interests regularly as well as repay principal as at when due.

\subsection{Hypotheses}

Following the review of related literature, the following four hypotheses, which are stated in the alternative form are tested in the paper:

H1 There are significant differences between working capital items of not-at-risk firms and at-risk firms. 
H2 There are significant differences between financial leverage of not-at-risk firms and at-risk firms.

H3 For all firms, there is a significant association between working capital items and financial leverage.

H4 The association (if any) between working capital items and financial leverage of not-at-risk firms and at-risk firms are not equal.

\section{Research design and methodology}

\subsection{Sample, data source and data collection method}

The sample size consists of 89 non-financial services companies that are quoted or listed on the Nigerian Stock Exchange (NSE) as at 2015. As at that time, there were a total of one hundred and twenty-two (122) quoted non-financial services firms on the NSE. The sample size represents approximately 73 per cent of all non-financial services companies quoted in Nigeria. The 89 firms were used in the analyses based on data availability on all research variables from the firms' online annual financial statements. The following filters were also applied in drawing the sample: First, we required that the firms must not be a financial services firm. We exclude financial services companies because their working capital and leverage level is highly regulated by the Central Bank of Nigeria $(\mathrm{CBN})$, especially in view of the CBN's capital adequacy requirement; and Basle Accords bank capitalisation requirements. Second, we required that the firms must have their 2015 year-end downloadable complete financial statements on the internet, either on the firms' own websites or on that of the Nigerian Stock Exchange at http://www.nse.ng. The sample composition by industry membership, risk vulnerability grouping, and number of firms is shown in Table 1.

Table 1 Industry membership, risk vulnerability grouping and number of firms

\begin{tabular}{|c|c|c|c|}
\hline & Pooled sample & Not-at-risk sample & At-risk sample \\
\hline & No. & No. & No. \\
\hline Agriculture & 5 & 1 & 4 \\
\hline Healthcare & 9 & 4 & 5 \\
\hline Construction and real estates & 4 & 2 & 2 \\
\hline Oil and gas & 10 & 7 & 3 \\
\hline Natural resources & 3 & - & 3 \\
\hline Consumer goods & 17 & 11 & 5 \\
\hline Industrial goods & 15 & 5 & 10 \\
\hline Services & 15 & 6 & 9 \\
\hline Conglomerate & 7 & 6 & 1 \\
\hline ICT & 4 & 2 & 2 \\
\hline Total & 89 & 44 & 44 \\
\hline
\end{tabular}


The Nigerian Stock Exchange classifies 11 industry subsectors from which we were able to collect company data of ten subsectors including agriculture (five firms), healthcare (nine firms), construction and real estates (four firms), oil and gas (ten firms), natural resources (three firms). Others include consumer goods (17 firms), industrial goods (15 firms), services (15 firms), conglomerate (seven firms), and ICT (four firms). The industry subsector distribution by grouping and number can be seen in Table 1. The sample size used by this paper compares well with those of prior Nigerian papers especially that of Asien (2015), who used 83 companies in his study. To the best of our knowledge, Asien (2015) used one of the highest sample sizes in an empirical Nigerian research.

\subsection{Operationalisation and measurement of variables}

This section operationalises how the research variables are measured in this paper.

Net current assets are measured as the difference between total current assets and total current liabilities. Liquidity ratio is measured by dividing total current assets by total current liabilities. Quick ratio is measured by dividing total current assets minus closing inventory by total current liabilities. Cash ratio is measured as cash and cash equivalents divided by total current liabilities. High (low) values of the above ratios are indications that current assets are more (less) than total current liabilities.

Cash conversion cycle is the number of days elapsing between the time it takes to purchase materials on credit, sell the finished goods produced to customers on credit, and receive cash from customers. It is calculated as account receivables days plus inventory days minus account payables days. The longer (shorter) the cash conversion cycle, the longer (shorter) days it takes a firm to receive cash. We measure financial leverage as total long-term debt to total long-term debt plus shareholders' equity. All the variables are elements of statement financial position. Cash conversion cycle is a hybrid item as it belongs to both the income statements/statement of comprehensive income as well as statement of financial position.

\subsection{Method of testing Hypotheses $\mathrm{H} 1$ and $\mathrm{H} 2$}

Following the methodology of Afrifa (2016), we bifurcate the 89 non-finance firms into two groups of 44 apiece. The formation of the two groups enables us to employ paired samples tests to test for the mean (median) differences between working capital items and financial leverage of not-at-risk firms against at-risk firms. The median (or 45th) company is regarded as a neutral point of reference, which is isolated. We refer to it as the target/optimal risk firm. The first 44 firms are at-risk or vulnerable to working capital items risk because their working capital values are below those of the target. The second 44 firms are not-at-risk or in good financial health because their working capital items values are above those of the target. For ease of exposition, we are testing for mean (median) differences in net current assets, liquidity ratio, acid-test (quick) ratio, cash ratio, and cash conversion cycle of not-at-risk and at-risk companies. 


\subsection{Method of testing Hypotheses $\mathrm{H} 3$ and $\mathrm{H} 4$}

We think that robustness of working capital items can be significantly associated with long-term debt financing or financial leverage of all firms, irrespective of their risk vulnerability status, Hypothesis $\mathrm{H} 3$. We also think that the association between working capital items and financial leverage is likely to be different for not-at-risk firms and at-risk firms, Hypothesis $\mathrm{H} 4$.

We run three separate cross-sectional multiple regressions for the three groups.

\subsection{The model}

Our model follows prior literature (Akinlo, 2011; Moosa and Sbeti, 2012). According to Moosa and Sbeti (2012), the methodology typically used in studies of capital structure is based on regressions of the form,

$$
L E V=\alpha_{0}+\sum_{t=1}^{n} \beta_{i} x_{i}+\varepsilon
$$

where $L E V=$ financial leverage ratio, $\alpha_{0}$ is a constant term, $\beta_{i}$ is coefficient of $x_{i}$, the explanatory variables. In specific terms, equation (1) is expanded in this paper to incorporate three separate cross-sectional OLS regression models below:

$$
\begin{aligned}
L E V_{p}= & \alpha_{0 p}+\beta_{1} N C A_{p}+\beta_{2} L I Q_{p}+\beta_{3} Q_{U I C_{p}}+\beta_{4} C S H_{p}+\beta_{5} C C C_{p} \\
& +\beta_{6} I N D_{p}+\varepsilon_{p} \\
L E V_{N A}= & \alpha_{0 N A}+\beta_{1} N C A_{N A}+\beta_{2} L I Q_{N A}+\beta_{3} Q U I C_{N A}+\beta_{4} C S H_{N A}+\beta_{5} C C C_{N A} \\
& +\beta_{6} I N D_{N A}+\varepsilon_{N A} \\
L E V_{A R}= & \alpha_{0 A R}+\beta_{1} N C A_{A R}+\beta_{2} L I Q_{A R}+\beta_{3} Q U I C_{A R}+\beta_{4} C S H_{A R}+\beta_{5} C C C_{A R} \\
& +\beta_{6} I N D_{A R}+\varepsilon_{A R}
\end{aligned}
$$

where $N C A=$ net current assets, $L I Q=$ liquidity ratio, $Q U I C=$ quick ratio, $C S H=$ cash ratio, $C C C=$ cash conversion cycle, and $I N D=$ industry membership. $\varepsilon=$ i.i.d. error term, with zero mean. $\alpha_{0}=$ intercept of the equations while $\beta$ is the regression coefficient. The subscript $p, N A$ and $A R$ in equations (2.1), (2.2) and (2.3) represents data of the pooled sample, not-at-risk sample, and at-risk sample; respectively.

$L E V$ (financial leverage) is the dependent variable in the equations. The independent variables are NCA, LIQ, QUIC, CSH and CCC. IND is industry membership, and is the control variable ${ }^{3}$. Note that the models do not imply any causality but merely examine the relation between financial leverage and working capital items. The choice of the independent variables is guided by extant literature such as Lin et al. (2011), Coyne et al. (2012), especially, Altman and Rijken (2012) and Moosa and Sbeti (2012). Instructively, all the variables in the cited prior works are working capital items. The intuitive belief that working capital imperatives can influence financial leverage leads to hypothesising a positive relationship between financial leverage and elements of working capital. All the tests conducted in this paper were implemented on the Statistical Package for Social Sciences (SPSS) version 21. 


\section{Empirical results}

This section presents the results of the study. Subsection 4.1 presents the result of test of Hypotheses $\mathrm{H} 1$ and $\mathrm{H} 2$ while subsection 4.2 presents tests result of Hypotheses $\mathrm{H} 3$ and H4.

\subsection{Result of test of Hypotheses $\mathrm{H} 1$ and $\mathrm{H} 2$}

The descriptive statistics of all the research variables of the three panels are contained in Tables $2 \mathrm{a}$ and $2 \mathrm{~b}$.

Table 2a Descriptive statistics for working capital items

\begin{tabular}{|c|c|c|c|c|c|c|}
\hline & \multicolumn{2}{|c|}{ Panel $A$} & \multicolumn{2}{|c|}{ Panel B } & \multicolumn{2}{|c|}{ Panel C } \\
\hline & \multicolumn{2}{|c|}{ Pooled sample $(N=89)$} & \multicolumn{2}{|c|}{ Not-at-risk sample $(N=44)$} & \multicolumn{2}{|c|}{ At-risk sample $(N=44)$} \\
\hline & Mean & Median & Mean & Median & Mean & Median \\
\hline$N C A$ & $-1,552,247.04$ & $60,413.00$ & $3,045,188.39$ & $1,101,587.50$ & $-6,186,333.84$ & $-1,230,041.50$ \\
\hline$L I Q$ & 1.876292 & 1.078000 & 3.089678 & 1.831275 & .681011 & .785750 \\
\hline QUIC & 1.194944 & 1.078000 & 2.207498 & 1.078910 & .193709 & .380300 \\
\hline$C C C$ & -16.774528 & 3.461000 & 71.333151 & 47.054639 & -105.342239 & -49.576100 \\
\hline $\mathrm{CSH}$ & .215876 & .080000 & .428354 & .438909 & .006407 & .000000 \\
\hline
\end{tabular}

Table 2b Descriptive statistics for financial leverage

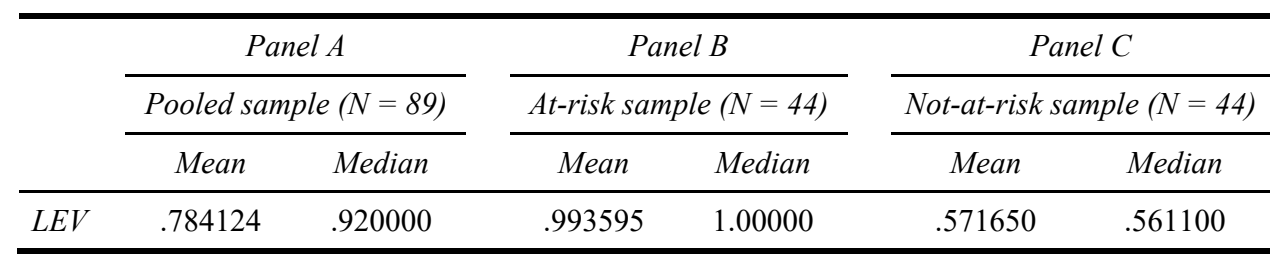

Considering panels $\mathrm{B}$ and $\mathrm{C}$ in Table $2 \mathrm{a}$, it can be seen that on all variables the mean and median values of not-at-risk firms are higher than the mean and median values of at-risk firms. Notice that the differences in these values are very high. Interestingly, average net current assets $(N C A)$ and average cash conversion cycle $(C C C)$ of the pooled and the at-risk samples are negative. The negative net current asset implies that total current assets are less than total current liabilities of the pooled and at-risk panels. Financial leverage statistics are contained in Table $2 \mathrm{~b}$. It can be seen in Table $2 \mathrm{~b}$, panels B and C, that the mean and median values of financial leverage of not-at-risk companies are lower than the mean and median values of at-risk companies. Recall by our definition that high (low) values of leverage ratios indicate high (low) risk vulnerability. 
Table 3a Paired samples tests of working capital items

\begin{tabular}{|c|c|c|c|c|c|c|c|}
\hline & \multicolumn{2}{|c|}{ Paired differences } & \multirow{2}{*}{$t$} & \multirow{2}{*}{$d f$} & \multirow{2}{*}{$\begin{array}{c}\text { Sig. } \\
\text { (two-tailed) }\end{array}$} & \multirow{2}{*}{$Z$} & \multirow{2}{*}{$\begin{array}{l}\text { Asymp. sig. } \\
\text { (two-tailed) }\end{array}$} \\
\hline & Mean & Std. deviation & & & & & \\
\hline $\begin{array}{l}N C A \text { not-at-risk - } \\
N C A \text { at-risk }\end{array}$ & $9,231,522.227$ & $16,773,799.053$ & 3.651 & 43 & .001 & -5.777 & .000 \\
\hline $\begin{array}{l}L I Q \text { not-at-risk- } \\
L I Q \text { at-risk }\end{array}$ & 2.4086669 & 3.1698412 & 5.040 & 43 & .000 & -5.777 & .000 \\
\hline $\begin{array}{l}\text { QUIC not-at-risk - } \\
Q U I C \text { at-risk }\end{array}$ & 2.0137890 & 2.5828548 & 5.172 & 43 & .000 & -5.777 & .000 \\
\hline $\begin{array}{l}C C C \text { not-at-risk - } \\
C C C \text { at-risk }\end{array}$ & 176.6753896 & 189.1799798 & 6.195 & 43 & .000 & -5.777 & .000 \\
\hline $\begin{array}{l}\mathrm{CSH} \text { not-at-risk - } \\
\mathrm{CSH} \text { at-risk }\end{array}$ & .4219475 & .2175154 & 12.868 & 43 & .000 & -5.777 & .000 \\
\hline
\end{tabular}

Table 3b Paired samples test of financial leverage

\begin{tabular}{|c|c|c|c|c|c|}
\hline & \multicolumn{2}{|c|}{ Paired differences } & \multirow{2}{*}{$t$} & \multirow{2}{*}{$d f$} & \multirow{2}{*}{$\begin{array}{c}\text { Sig. } \\
\text { (two-tailed) }\end{array}$} \\
\hline & Mean & Std. deviation & & & \\
\hline$L E V$ not-at-risk $-L E V$ at-risk & -.4219453 & .2175206 & -12.867 & 43 & .000 \\
\hline
\end{tabular}

\subsubsection{Paired samples tests}

Table 3 presents the results of paired samples test of the research variables. Table 3a contains the test results of working capital items of not-at-risk and at-risk companies while Table $3 \mathrm{~b}$ contains test results of financial leverage of the same firms.

At the $1 \%$ level, Table $3 \mathrm{a}$ shows that there are positive significant differences between working capital items of not-at-risk firms and those of at-risk firms. Per the adopted definition of financial leverage in this paper, firms with higher (lower) total long-term debt-to-total long-term debts plus shareholders' equity face greater (lesser) financial risks. Not-at-risk companies face lesser financial risk than their at-risk counterparts. Hence, it can be seen from Table $3 \mathrm{~b}$ that the negative mean difference of $-.4219453=.57165-.993595$ between financial leverage of not-at-risk companies and financial leverage of at-risk companies are statistically significant, sig. $\rho<.010$. Together, these two results are consistent with Hypotheses H1 and H2. The financial leverage statistic for the pooled sample has an average of .784124 , suggesting consensus high level of financial risk of the combined firms. The same monotonic analysis holds for the median values of the three panels.

\subsubsection{Bivariate correlations analysis}

Bivariate correlations result is shown in Table 4. Correlations between financial leverage $(L E V)$ and all research variables are positive and significant. The highest among them is that between financial leverage and cash conversion cycle $(C C C)$ at .690 . As expected, correlations among the working capital items are high, significant and positive, which imply that as one variable increases the others increase as well. Highest correlation (.981) among the working capital variables is between liquidity ratio (LIQ) and quick ratio $(Q U I C)$. This is followed by the correlation (.773) between cash conversion cycle ratio $(C C C)$ and net current assets $(N C A)$. 
The high correlations among working capital items are expected because all working capital items are related. To support these correlation results, Altman (2000) argues that to utilise related set of working capital items and financial leverage in assessing corporates' financial risk can portray a high degree of correlation or collinearity with each other. This is what the correlations in Table 4 have shown.

Table 4 Pearson bivariate correlations matrix $(\mathrm{N}=89)$

\begin{tabular}{llccccc}
\hline & $L E V$ & $N C A$ & $L I Q$ & QUIC & $C S H$ & $C C C$ \\
\hline$N C A$ & $.577^{* *}$ & & & & & \\
& $(.000)$ & & & & & \\
$L I Q$ & $.419^{* *}$ & $.454^{* *}$ & & & & \\
& $(.000)$ & .000 & & & & \\
QUIC & $.460^{* *}$ & $.545^{* *}$ & $.981^{* *}$ & & & \\
& $(.000)$ & .000 & .000 & & & \\
$C S H$ & $.661^{* *}$ & $.400^{* *}$ & $.762^{* *}$ & $.741^{* *}$ & & \\
& $(.000)$ & .000 & .000 & .000 & & \\
$C C C$ & $.690^{* *}$ & $.773^{* *}$ & $.649^{* *}$ & $.675^{* *}$ & $.583^{* *}$ & \\
& $(.000)$ & .000 & .000 & .000 & .000 & $.025 *$ \\
$I N D$ & $.228^{*}$ & $.254^{*}$ & -.070 & -.039 & .041 & .034 \\
& $. .031)$ & .016 & .516 & .716 & .703 & .034 \\
\hline
\end{tabular}

Notes: **Correlation is significant at the 0.01 level (two-tailed).

*Correlation is significant at the 0.05 level (two-tailed).

\subsection{Result of test on Hypothesis H3}

We go beyond correlational analysis to conduct multiple regression tests in respect of Hypotheses H3 and H4. We report the result of the multivariate test on Hypothesis H3, which relates to the pooled sample. This is conveyed in panel A of Table 5.

Overall, the test results in panel A, and indeed, the two other panels, are statistically significant, except for net current assets and industry-membership. At the $1 \%$ level, liquidity ratio $(\mathrm{t}=-3.326)$ has negative significant association with financial leverage. This suggests that liquidity ratio and financial leverage move in the opposite direction. Cash ratio $(\mathrm{t}=7.312)$ and cash conversion cycle $(\mathrm{t}=4.655)$ have positive significant association with financial leverage. At the $5 \%$ level, quick ratio $(\mathrm{t}=2.209)$ has positive significant association with financial leverage. By interpretation, the result on liquidity ratio suggests that a unit increase in liquidity reduces financial leverage by approximately $135 \%$. This can be interpreted to suggest that companies that are liquid may reduce their long-term debts. Regarding the quick (acid-test) ratio and cash ratio, it appears that a unit increase in quick ratio and cash ratio increases financial leverage by about $89 \%$ and $71 \%$, respectively. When interpreted in light of the relationship between liquidity ratio and quick (acid-test) ratio, this result is not surprising. It is straightforward to think that as companies remove closing inventories from their current assets, they may require increased financing, perhaps, by getting more long-term debt financing. It may happen that companies that are awash with cash may actually engage in borrowing if they are aggressive or ambitious as a result of overtrading. 
Table 5 Multivariate analysis of financial leverage and working capital items of not-at-risk and at-risk firms

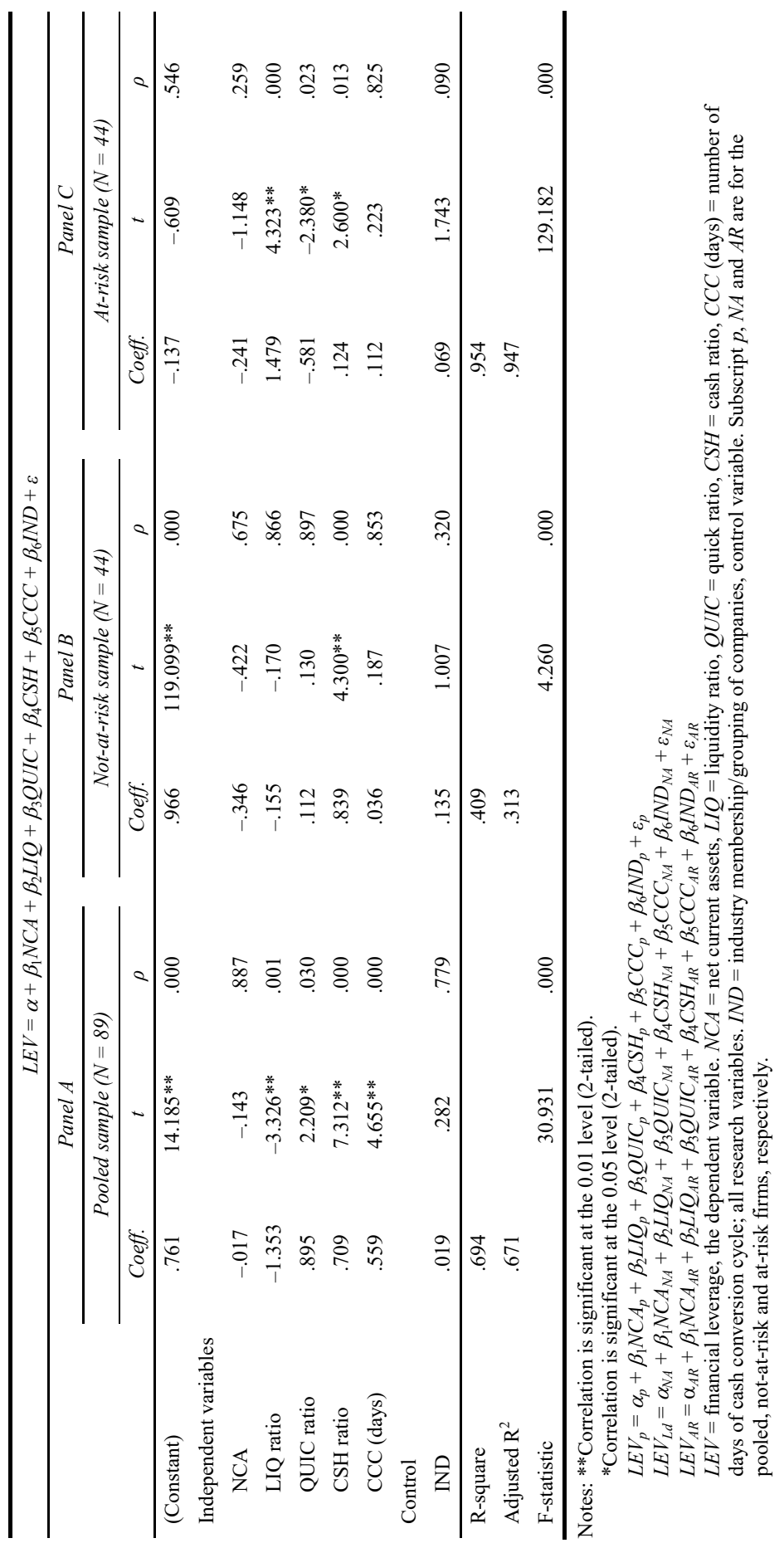


Concerning the result on cash conversion cycle days, the result in panel A suggests that an increase in cash conversion cycle by one day is likely to increase financial leverage by about $56 \%$. When companies' cash conversion cycle lengthens the companies are likely to go into more debt to finance their activities, hence the observed positive association. As for the explanatory power (adjusted $\mathrm{R}^{2}$ ) of the pooled model, the independent variables explain about $67 \%$ of the variation in financial leverage. The remaining $33 \%$ is left to other factors not considered in this paper.

\subsection{Test of Hypothesis H4}

Finally, we report the result of the multivariate tests of Hypothesis H4, on the differences between not-at-risk firms and at-risk firms, and the association between financial leverage and working capital items. We compare the test results of not-at-risk firms against those of at-risk firms. Continuing with Table 5, the test results of the not-at-risk firms and the at-risk firms are contained in panels B and C, respectively. Recall that $\mathrm{H} 4$ states that the association (if any) between working capital items and financial leverage of not-at-risk and at-risk firms are not equal. It can be seen from Table 5 that there is a significant positive association between cash ratios and financial leverage ratios of both not-at-risk and at-risk firms. For the not-at-risk group, it is significant at the $1 \%$ level $(\mathrm{t}=4.300)$ while it is significant for the at-risk group at the $5 \%$ level $(\mathrm{t}=2.600)$. It is only on the cash ratio $(\mathrm{CSH})$ that there is a similar result between at-risk and not-at-risk companies. Regarding the association between the remaining working capital variables and leverage, the test result suggests that net current assets, liquidity ratio, quick ratio, and cash conversion cycle of not-at-risk and at-risk groups are (not) associated with financial leverage in the same ways. In particular, the research variables (net current assets and cash conversion cycle), and the control variable (industry membership) are not significantly associated with financial leverage of the two group of firms. Notice that as it was with the pooled sample, the observed signs of net current assets, cash conversion cycle and industry membership are similar in the case of not-at-risk group and at-risk group. On this note, both not-at-risk group and at-risk group exhibit similar risk vulnerability relationship/characteristic with financial leverage. That is, there is no significant association between the two groups' working capital items and their financial leverage. For both groups, net current assets ratio and cash conversion cycle behave in similar ways. For both groups, net current assets are negative while cash conversion cycles are positive.

It can further be seen from panels $\mathrm{B}$ and $\mathrm{C}$ of Table 5 that the tests on liquidity ratio and quick ratio indicate mixed results as the two groups behave differently. For the not-at-risk firms, the two ratios in question are not significantly associated with financial leverage. However, the two ratios are significantly associated with financial leverage for the at-risk firms alone: liquidity ratio $(\mathrm{t}=4.323, \rho=.000)$ is positively associated with financial leverage at the $1 \%$ level while quick ratio $(\mathrm{t}=-2.380, \rho=.023)$ is negatively associated with financial leverage at the 5\% level. By interpretation, it means that a unit rise (fall) in liquidity (quick) ratio is likely to increase (reduce) financial leverage of at-risk group by about $148 \%(58 \%)$. This is not the case with the not-at-risk firms where there is no significant relationship between any of the working capital variables and financial leverage, except for cash ratio. Absent the change in sign, the result on liquidity and quick ratios is consistent with $\mathrm{H} 4$. In the case of at-risk group, our finding that 
financial leverage is positively related to liquidity is consistent with Akinlo (2011). We note quickly that Akinlo (2011) did not find a significant relationship. Differences in coefficient estimates can be used to further analyse the differences in associations between working capital items and financial leverage of not-at-risk firms and at-risk firms. Coefficient of $L I Q$ ratio of not-at-risk (-.155) is lower than coefficient (1.479) of at-risk companies; the QUIC ratio coefficient (.112) of not-at-risk companies is higher than coefficient (-.581) of QUIC ratio of at-risk companies. The coefficient of $C C C$ (days) (.036) of not-at-risk companies is lower than the coefficient (.112) of at-risk companies. Furthermore, the coefficient (.839) of not-at-risk companies is higher than the coefficient (.124) of at-risk companies. These results suggest that the association between working capital items and financial leverage of not-at-risk companies and at-risk companies are not equal.

In sum, the foregoing analyses suggest that, except for cash ratio, the association between working capital items and financial leverage of not-at-risk firms and at-risk firms are not equal.

This result is largely consistent with Hypothesis H4. We notice the curious change in signs of liquidity ratio and quick ratio between the pooled sample and the at-risk group. While liquidity (quick) ratio is negative (positive) for the pooled sample, the reverse is the case for the at-risk companies. For the pooled sample, when liquidity (quick) ratio falls (increases) financial leverage increases (falls). For at-risk companies, when liquidity (quick) ratio increases (falls) financial leverage falls (increases). We refrain from pursuing this point further.

Finally, the explanatory powers as illustrated with adjusted $R^{2}$ of the two groups' models are different in accounting for the variation in financial leverage. The independent variables explain about $31 \%$ and $94.7 \%$ of the variation in financial leverage of the not-at-risk firms and the at-risk firms, respectively. For the not-at-risk companies, only cash ratio is significantly related to financial leverage. And for the at-risk firms, liquidity ratio, quick ratio, and cash ratio are significantly related to financial leverage. In summary, the cash ratio is positively related to leverage for all three panels. This finding implies, on average, that increases in cash ratio significantly increases financial leverage.

\subsection{Robustness check}

We carried out a robustness check by removing the control variable (IND) from the regression runs. The result (not tabulated) shows that the result earlier reported is quantitatively and economically unchanged, an indication that the result is not sensitive to the inclusion (non-inclusion) of industry membership-induced influences.

\section{Conclusions and recommendation}

In this paper, we compare risk vulnerability of 89 Nigerian non-finance firms on selected financial metrics involving working capital items and leverage, and examine the association between working capital items and financial leverage of the firms. We 
bifurcate 89 non-finance firms into two groups of 44 each. We refer to the two groups as either not-at-risk firms or at-risk firms. We use paired samples test to compare mean and median differences in working capital items and financial leverage of not-at-risk firms against those of at-risk firms. Thereafter, we used multiple regression methods to examine the association between working capital and financial leverage of the firms.

Results of paired samples tests (reported in Tables 3a and 3b) show that there are statistically significant differences between working capital and financial leverage ratios of not-at-risk and at-risk firms. We, therefore, conclude that at-risk firms face higher financial risk vulnerability than not-at-risk firms. The relationship between working capital and leverage as re-presented in Table 6 (a transplant of Table 5) shows the following: For the pooled sample, we find that liquidity ratio has negative significant association with financial leverage while quick ratio, cash ratio and cash conversion cycle have positive significant association with financial leverage.

We find a significant positive association between cash ratio and financial leverage ratio of not-at-risk firms and at-risk firms. We conclude that even though firms have enough cash they could still borrow to augment their capital structure, irrespective of whether they are at-risk or not-at-risk category. Comparatively, not-at-risk firms and at-risk firms are dissimilar in liquidity and quick ratios. For not-at-risk firms, liquidity ratio and quick ratio are not significantly associated with financial leverage. However, for at-risk firms, liquidity ratio is significant and positively associated with financial leverage while the quick ratio is significant and negatively associated with financial leverage. What this means for the at-risk group is that a unit rise in liquidity ratio is likely to increase financial leverage (hence, financial risk vulnerability) by about $148 \%$ while a fall in quick ratio is likely to reduce financial leverage by about $58 \%$. Regarding the not-at-risk group, except for cash ratio, there is no significant relationship between working capital items and financial leverage. In sum, except for cash ratio, we can conclude that the association between working capital items and financial leverage is not equal for the not-at-risk and at-risk samples, a result that is largely consistent with Hypothesis H4.

Explanatory powers as conveyed by adjusted $R^{2}$ of the three groups differ. For the full/pooled sample, the independent variables explain about $67 \%$ of the variation in financial leverage. For the not-at-risk firms, the same variables explain about $31 \%$ of the variation in financial leverage while for the at-risk firms the variables explain $94.7 \%$ of the variation in financial leverage. On the strength of the findings reported in this paper, we recommend that even though firms have enough cash they could still borrow to shore up their capital structure.

One important contribution of the paper is that the method of demarcating at-risk companies from not-at-risk companies can be applied in checking the financial health of non-finance companies in Nigeria in the absence of credit ratings of most of these companies in Nigeria.

There are two main limitations that pose a challenge to this paper: the research data were drawn from only Nigerian companies, which may not be sufficient to generalise to all developing economies; and only one year's annual financial statements data were used, which can prevent inter-temporal analysis. 
Table 6 Multivariate analysis of financial leverage and working capital items of not-at-risk and at-risk firms

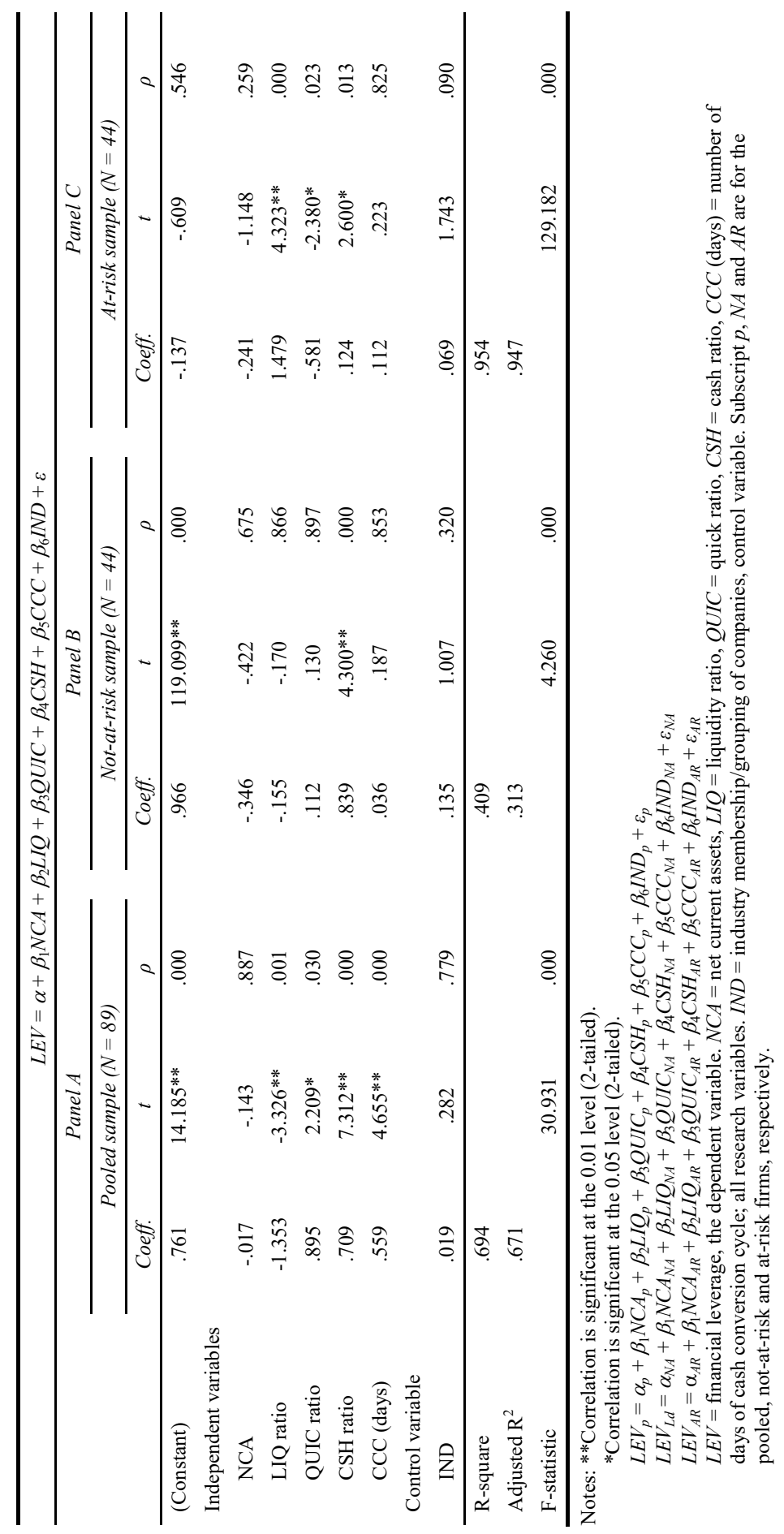




\section{References}

Afrifa, G.A. (2016) 'Net working capital, cash flow and performance of UK SMEs', Review of Accounting and Finance, Vol. 15, No. 1, pp.21-44.

Akinlo, O. (2011) 'Determinants of capital structure: evidence from Nigerian panel data', African Economic and Business Review, Vol. 9, No. 1, pp.1-16.

Altman, E. I. and Rijken, H. (2012). 'Toward a bottom-up approach to assessing sovereign default risk: an update', International Research Journal of Applied Finance, Vol. 3, No. 2, pp.118-136.

Altman, E.I. (2000) Predicting Financial Distress of Companies: Revisiting the Z-score and ZETA ${ }^{\circledR}$ Model, Working paper, Stern School of Business, New York University, New York.

Amélia, P.M. and Gama, P.M. (2015) 'Working capital management and SMEs profitability: Portuguese evidence', International Journal of Managerial Finance, Vol. 11, No. 3, pp.341-358.

Asien, E.N. (2015) 'Audit regimes and audit market concentration in Nigeria', ICAN Journal of Accounting and Finance, Vol. 4, No. 1, pp.33-54.

Coyne, C., Haverty, J.L. and Lin, J. (2012) 'A comparison of the financial characteristics of pharmaceutical firms in the United States and the People's Republic of China', International Research Journal of Applied Finance, Vol. 3, No. 7, pp.889-902.

Falope, O. and Ajilore, O. (2009) 'Working capital management and corporate profitability: evidence from panel data analysis of selected quoted companies in Nigeria', Research Journal of Business Management, Vol. 3, No. 3, pp.73-84.

Fama, E.F. and French, K.R. (2000) Testing Tradeoff and Pecking Order Predictions about Dividends and Debt, Working paper, University of Chicago and the Sloan School of Management (MIT).

Frank, M. and Goyal, V.K. (2009) 'Capital structure decisions: Which factors are reliably important?', Financial Management, Vol. 38, No. 1, pp.1-37.

Gumparthi, S., Khatri, S. and Manickavasagam, V. (2011) 'Design and development of credit rating model for public sector banks in India: special reference to small and medium enterprises', Journal of Accounting and Taxation, Vol. 3, No. 5, pp.105-124.

Hutchison, P.D., Farris II, M.T. and Anders, S.B. (2007) 'Cash-to-cash analysis and management', The CPA Journal, Vol. 77, No. 8, pp.42-47.

Kargar, J. and Blumenthal, R.A. (1994) 'Leverage impact of working capital in small businesses', TMA Journal, Vol. 14, No. 6, pp.46-53.

Lin, Y., Li, S. and Lin, S. (2011) 'The impact of credit rating on firm valuation - evidences from the photonics corporations in Taiwan', International Research Journal of Applied Finance, Vol. 2, No. 12, pp.1482-1492.

Lungu, C.I., Caraiani, C., Dascalu, C. and Guse, G.R. (2010) 'Social and environmental determinants of risk and uncertainties reporting', Issues in Social and Environmental Accounting, Vol. 3, No. 2, pp.100-116.

Lyngstadaas, H. and Berg, T. (2016) 'Working capital management: evidence from Norway', International Journal of Managerial Finance, Vol. 12, No. 3, pp.295-313.

Minton, B. and Schrand, C. (1999) 'The impact of cash flow volatility on discretionary investment and the costs of debt and equity financing', Journal of Financial Economics, Vol. 54, No. 3, pp.423-460.

Moosa, I. and Sbeti, W. (2012) 'The determinants of capital structure in a tax-free environment: an extreme bounds analysis', International Research Journal of Applied Finance, Vol. 3, No. 6, pp.865-881.

Myers, S.C. (1977) 'Determinants of corporate borrowing', Journal of Financial Economics, Vol. 5, No. 6, pp.147-175. 
Rajan, R.G. and Zingales, L. (1995) 'What do we know about capital structure? Some evidence from international data', Journal of Finance, Vol. 50, No. 5, pp.1421-1460.

Ross, S.A., Westerfield, R.W. and Jordan, B.D. (2006) Fundamentals of Corporate Finance, 7th ed., McGraw-Hill Irwin, New York.

Singh, J.P. (2012) 'On the Intricacies of cash flow based corporate valuation', International Research Journal of Applied Finance, Vol. 111, No. 10, pp.1522-1541.

Thies, C. and Klock, M. (1992) 'Determinants of capital structure', Review of Financial Economics, Vol. 1, No. 6, pp.40-52.

Uremadu, S.O. and Efobi, R.U. (2012) 'The Impact of capital structure and liquidity on corporate profitability', International Journal of Academic Research in Accounting, Finance and Management Sciences, Vol. 2, No. 3, pp.1-16.

Uremadu, S.O., Egbide, B. and Enyi, P.E. (2012) 'Working capital management, liquidity and corporate profitability among quoted firms in Nigeria: evidence from the productive sector returns in Nigeria', International Journal of Academic Research in Accounting, Finance and Management Sciences, Vol. 2, No. 1, pp.80-97.

Wasiuzzaman, S. (2015) 'Working capital and firm value in an emerging market', International Journal of Managerial Finance, Vol. 11, No. 1, pp.60-79.

\section{Notes}

1 Following Myers (1977) and Moosa and Sbeti (2012), in this paper, references to financial leverage imply book financial leverage rather than market financial leverage. This distinction becomes necessary because of uncertainties associated with the latter. The distinction is discussed in Frank and Goyal (2009). Nevertheless, we note the controversies that exist in the literature as to which definition of leverage is the most appropriate. Some of this literature will be reviewed in Section 2 of this paper.

2 The shortcomings of these four alternative definitions are covered in Moosa and Sbeti (2012).

3 Falope and Ajilore (2009) find no significant variations in the effects of working capital management of large and small firms. On the strength of this, we did not control for firm size in this paper. 